\title{
A New Way to Promote Islamization of Science: I-SETS Design for Pre-Service Science Teachers
}

\author{
Muhamad Imaduddin ${ }^{1}$ \\ ${ }^{1}$ Institut Agama Islam Negeri Kudus \\ e-mail: \\ 1 imad@iainkudus.ac.id
}

\begin{abstract}
.
The development of science, especially natural science apart from religion ultimately raises a theological problem. The intersection between science and religion is contained in the National Curriculum respecting religious attitudes. Educators are expected to present meaningful integrated science to equip learners with skills to participate fully in society. This study aims to design an ISETS (Islamic-Science, Environment, Technology, and Society) integrated learning for pre-service science teachers. The literature study was used in studying western and Islamic science, Golshani's Islamization of science paradigm and I-SETS vision. The design is based on learning levels: ISETS foundation, I-SETS issues awareness, I-SETS issues investigation, and action skills development. This design is expected to be an alternative raw model that will be applied by preservice science teachers at various levels.
\end{abstract}

Keywords: Learning design, I-SETS vision; Islamization of science; pre-service science teachers.

\section{INTRODUCTION}

Along with the development of science and technology in the 21 st century, there has been a shift in both the characteristics and the model of learning. This is anticipated through the presence of the national curriculum applied in Indonesia. In this national curriculum, science subjects at junior high school level (Sekolah Menenengah Pertama/Madrasah Tsanawiyah, $\mathrm{SMP} / \mathrm{MTs}$ ) are packaged in integrated science (physics, biology, chemistry, as well as earth and space science), and integrated with character formation, including religious character. Besides, the National Science Teachers Association has also recommended that science teachers at the elementary and secondary levels should have the ability to develop a thematic and interdisciplinary science lesson (National Science Teachers Association, 2003). The changes in teachers' educational paradigms and mindsets must be based on what skills these students will need in the 21 st century to achieve full participation in society.

The Center of Educational Curriculum, the Center for Research and Development, Ministry of National Education of Indonesia has developed guidelines for the development of integrated science learning since 2005. Nevertheless, the reality on the ground is not that all science teachers of SMP/MTs apply integrated science learning for various reasons (Wilujeng, 2010). The teachers' understanding of the concept of integrated science was still a lot of error in the concept. Starting from the demands of curriculum change related to the presentation of integrated science subject in SMP/MTs, the study program of Science Education began to be held in various universities, both Public University (Perguruan Tinggi Umum/PTU) and Islamic 
Religious Higher Education (Perguruan Tinggi Keagamaan Islam/PTKI). This is intended to prepare students as pre-service science teachers in SMP/MTs that have competence in integrated science.

The discourse on the integration of science and religion has emerged long enough. Although not always using the word "integration" explicitly, among modern Muslims the notion of the necessity of integration of science and religion, or reason and revelation (faith), has long been circulating. In this discussion, the names that often arise are Syed Muhammad Naquib AlAttas, Isma'il Al-Faruqi, and Ziauddin Sardar. Al-Attas called his original idea as "dewesternization of science", Isma'il Al-Faruqi explained the Islamization of Sciences; while Sardar carried the idea of "contemporary Islamic science". A physicist, Mehdi Golshani, who in the 1980s was popular with his work "The Holy Qur'an and Sciences of Nature", as the beginning of his efforts to integrate science with Islam (Muslih, 2010). In the context of Indonesia, the widespread idea of the need for the transformation of Islamic Higher Education (Institut Agama Islam Negeri/Sekolah Tinggi Agama Islam Negeri, IAIN/STAIN) into State Islamic University (Universitas Islam Negeri, UIN) or with the wider-mandate and the need for a review of the Islamic sciences is a major trigger for the study of the integration of science and religion (Minhaji, 2004). In the context of the Curriculum 2013 which is applied to the National Curriculum, the relationship between science and religion is manifested in the first Core Competence (Kompetensi Inti/KI 1). The Core Competencies (KI) are designed in four interrelated groups concerning religious attitudes (KI 1), social attitudes (KI 2), knowledge (KI 3), and application of knowledge (KI 4). The four groups become the reference of Basic Competency (Kompetensi Dasar/KD) and should be developed in each learning event integratively. Competencies related to religious and social attitudes are developed indirectly when learners learn about knowledge (KI 3) and knowledge application (KI 4) (Badan Penelitian dan Pengembangan, 2013).

In the historical-ideological context, the phenomenon of the dichotomy of science does not originate from the Islamic tradition. Islamic teachings do not recognize scientific dichotomy. All knowledge comes from the same source, Allah, the Almighty Creator of the Univers, embodied in qauliyah verses (al-Qur'an and Sunnah) and kauniyah verses (universe and content). The shift in the paradigm of science in Islam, from integration to dichotomy, can not be separated from modern civilization, especially characterized by a secular way of life (Minhaji, 2007). This view originated from the disharmonic relationship between church clergymen and scientists in Western Europe, who were shown by the death penalty for scientists whose scientific findings contradict the "fatwa" of the church. For example, Nicolaus Copernicus died in prison in 1543 AD, Michael Servet died burnt in 1553 AD, Giordano Bruno was murdered in 1600 AD, and Galileo Galilei died in prison in 1642 AD.

Because the relationship between religion and science in the West goes inharmoniously, did not take place in harmony, scientists went away from religion to carry out their scientific activities. As a result, science in the West developed with an anthropocentric paradigm and denied theocentric paradigm. More seriously, the development of science became secular and separated from religion and thus resulted in a crucial theological problem. Many Western scientists feel no longer need to involve God in their scientific argumentation. For them, God has ceased to be anything, including being the creator and keeper of the universe. This secular view then affects almost every part of the world, including the Islamic world. To end the paradigm of the science dichotomy and its various negative impacts, several Muslim scientists have initiated various science reintegration efforts, for example through the Islamization of science or similar movement which began to the campaign since the 1980s (Kosim, 2013). Islamization of science is essentially an effort to transform Islamic values into various fields of life, especially science (Salafudin, 2013).

Referring to the development of the National Education Curriculum applied in Indonesia, as well as efforts to integrate science and Islam, pre-service science teachers from the PTKI are expected to respond to the anxiety through reorganizing the community's understanding at the 
school level regarding knowledge reintegration. However, in addition to aspects of science reintegration, the process of preparing educators for science also has challenges about the scientific paradigm and its learning. The reality in practice and the results of various literature studies, it is found that there are still many educators who teach science at the level of knowledge and have not led to the science area trying to solve problems in the environment and society. It is not in line with Golshani's notion of Islamic science that science can be useful according to Islamic teachings if science: (1) can draw closer to God, (2) can help to develop Islamic society and realize its purpose, (3) can guide others, and (4) can solve various problems that exist in society (Golshani, 1998).

To align science education following Islam, I-SETS vision (Islamic-Science, Environment, Technology, and Society) is initiated in science learning to prepare pre-service science teachers, especially within PTKI. I-SETS vision is a way of view that is based on Islamic values to see and connect science with aspects of the environment, technology, and society. The I-SETS vision expects science learning to take place through inquiry and discussion based on Islamic aspects and values related to science and technology issues in the environment and society. In SETS visionary learning (without the Islamic aspect), SETS brings the message that to apply science (S-first) to the form of technology $(\mathrm{T})$ in meeting the needs of society ( $\mathrm{S}$-second), it is necessary to think about its implications on the environment (E) physically and mentally (Binadja, 2005). The addition of the Islamic aspect as a worldview will bridge the process of science reintegration into Islamic science practically (Imaduddin, 2019; Imaduddin \& Khafidin, 2018). Islamic science is a science that contains elements of Islam on the underlying aspect (Golshani, 2004). Furthermore, the teachings of Islam can enter the application area in the form of technology that can be utilized for society and the environment. I-SETS vision is expected to be a raw model that can be applied in presenting science learning by prospective educators of science in the future. The learning model of integration-interconnection between religion and science can be used as a solutive foundation on the negative stigma of a scientific dichotomy (Amril, 2018). Through the presentation of this article, it will be further discussed about the design of Islamic Integrated Science learning for preservice science teachers through the I-SETS vision.

\section{METHOD}

This study uses a qualitative approach that is a literary study type. The qualitative approach is a procedure that produces descriptive data in the form of words (speech) and writing. This approach is used to design I-SETS learning through analyzing documents related to the integrated science curriculum in SMP/MTs published by the Ministry of Education and Culture of The Republic of Indonesia (2013), expert's thinking on the concept of Islamization of science, as well as I-SETS vision and implementation of the curriculum. Following the type of data sources that rely on documentary data, the data collection uses the documentation method. Data analysis is done through the document analysis method. Design learning is verified with content analysis and their compatibility with the National Curriculum of SMP/MTs.

\section{FINDINGS AND DISCUSSION}

\section{The Design of I-SETS Vision in Integrated Science Learning for Pre-service Teachers}

Professional educators in science fields mean the experts in conveying science to learners. Science as a field of science, like other sciences, has an object or study material (ontology aspect), has a way of obtaining (epistemological aspect), and usefulness (axiological aspect). The object of science is the science process and products. On this basis, science learning involves learning processes including scientific courses (procedures), as well as product learning that consists of factual, conceptual, procedural, and metacognitive knowledge of science (Wisudawati \& 
Sulistyowati, 2014). Sardar explained that the Islamization of science must begin by constructing the Islamic world view with the main foothold, namely building Islamic Epistemology (Zainiyati, 2016). On the aspect of ontology, Islamic education seeks to answer the nature of the universe. This means that in the process of educating, science holds that humans and nature are closely related to the process of acquiring knowledge. The axiology is related to the values, goals, and targets to be achieved in science education, namely to realize pious, devout worshipers and fond of doing charity for the hereafter (Mahfud, 2018). The design of I-SETS vision for learning tries to engineer the instrumental input components as well as the segregation of social and environmental inputs to present and package the learning process leading to the Islamization of science

According to Dick \& Carey, Weils, Benety, the learning approach is the ethical-pedagogical content that accompanies the rational or intellectual, religious or spiritual, emotional, functional, exemplary, experiential, and experiential learning process activities. Learning strategies are specific ways that are used systematically and procedurally in the learning process to improve the quality of the process and learning outcomes. Learning methods are different ways of achieving different learning outcomes, under different conditions based on established learning competencies (lectures, discussions, frequently asked questions, etc.). The learning model is a conceptual framework that describes the procedure systematically in organizing learning experiences to achieve learning objectives (Dick \& Carey, 1994). In other words, the learning model is the wrapping of the learning process in which there are approaches, strategies, methods, and learning techniques.

The position of science in education at the elementary and secondary levels, since the $1600 \mathrm{~s}$, has been questioned by many parties. This problem, in the twentieth century, re-emerged among the people. Hurd (1991) cites the National Commission's 1883 report stating the need for a reconceptualization of learning objectives and a curriculum appropriate to the modern era. The science lesson, in which the teacher appreciates the learning objectives of memorizing the treasury of science and the language of the science experts, is often carried out merely by the acquisition of a set of concepts and principles. Thus, science obtained by learners in the school seems far from the problems they will face in their daily life. Nellist (1986), who was chair of ASE (Association for Science Education) in 1986, formulated the direction and need in science education. Learners are expected to benefit from science learning that is set in real life, associated with the context of the concept of science, social, economics, and technology (Wisudawati \& Sulistyowati, 2014). The central purpose of science learning is the maintenance of "literacy" of science in the students themselves.

In line with the aims of science literacy, the expected achievement of science literacy is related to the power and role of human beings themselves in the teachings of Islam, namely:

(1) Humans are given the ability to understand nature (Q.S. Al Baqarah [2]: 31), meaning that science is taught formally in schools as a means of studying and exposing the phenomena that exist around the students.

(2) Humans are given the role of Allah's caliph on earth (Q.S. Al-An'am [6]: 165). Science learned by students is expected not only limited information acquisition that stops at the level of understanding but is expected to be applied and created following the role of the human being as the caliph. The ability to understand nature and the position of God's caliph is accompanied by three things (Golshani, 2004):

(a) ability to use natural resources also known as taskhir (submission) (Q.S. Luqman [3]: 20),

(b) responsibility for: his own actions (Q.S. Al-Shaffat [37]: 21-24); other members of society (Q.S. Ali Imran [3]: 114); animals and other creatures (Q.S. Al-An'am [6]: 38),

(c) the ability to distinguish good and evil (Q.S. Al-Shams [91]: 78). 
The SETS vision is derived from a philosophical foundation that reflects the unity between the SETS elements by remembering the SETS elements in the acronym and the application in the educational context (Binadja, 2005). The addition of I (Islamic) aims to provide basic views derived from the main sources of Islamic knowledge, sourced from the Qur'an, Sunnah, and ijtihad Ulama'. Thus, I-SETS brings the message that science comes from the same source that is God the Creator, embodied in the qauliyah verses (al-Qur'an and Sunnah) and kaunīyah verses (the universe and its contents). Natural science (S, natural science or IPA) used in the form of technology ( $\mathrm{T}$, technology) in meeting the needs of society ( $\mathrm{S}$, society) requires thinking about the various implications on the environment (E, environment). The development of I-SETS as a worldview can be harmonized in a way that seeks to utilize God's gift to govern society for eternal happiness which is also called Divine Goals (Golshani, 1998). For these purposes, there are four concepts relevant to the moral orientation of science and technology development, namely: (1) useful knowledge, (2) balance, (3) purification of the soul and (4) avoiding unfounded judgments (Golshani, 2004). The linkage of I-SETS components and the moral orientation of science development is represented in Figure 1.

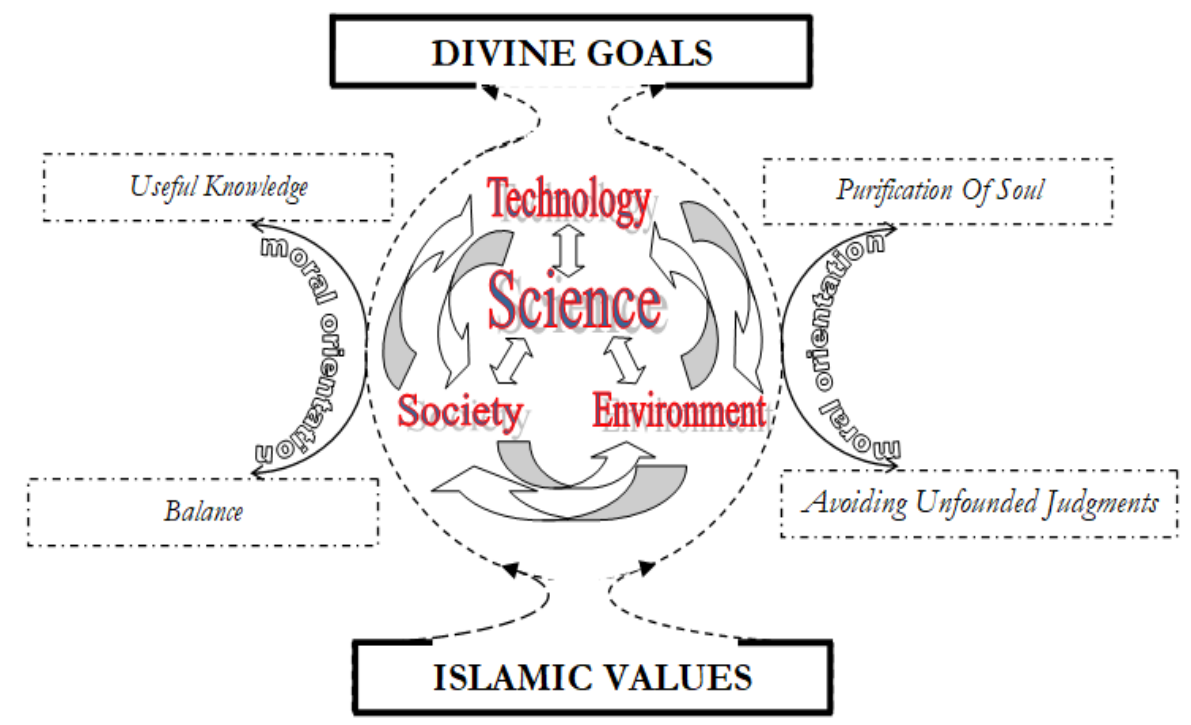

Figure 1. I-SETS vision in science learning

Natural Science (or science) is one field of scholarship that formally studied learners at various levels from the level of early childhood to university. The orientation of the development of subjects related to science leads to the moral concept of useful knowledge. Golshani expressed his thoughts about science as all kinds of human knowledge, whether about nature or the other, which are sourced from reason, senses or intuition, also from revelation. Human knowledge is divided into useful and unhelpful knowledge (Rifenta, 2019). The useful knowledge is the science that brings goodness to self and others in the life of the world and the hereafter. Any science that can not be good or harmful should not be sought or developed. Prophet Muhammad taught through his prayer O my Lord, I take refuge in You from science that is not useful (Allāhumma innī a' ŭdzubika min 'ilmi lā yanfa') (Golshani, 2004)

The existence of environmental components in the I-SETS vision shows the effort in maintaining the natural balance in accordance with the guidance of Islam. Balance becomes part of the development orientation because the basic tenets of Islam teach that nature is created in a balanced and orderly manner according to the order established by Allah SWT (Q.S. Al-Rahman [55]: 5-8). Therefore, all human activities and their interaction with nature must not undermine the order and balance. All destruction and exploitation are forms that violate the order and balance of the universe. Therefore it can not be justified according to religious ethics (Golshani, 2004). 
Purification of the soul into the orientation of science development, because the development of science is inseparable from the development of religiosity of self. Scientific activity is the activity of reading the verses of Allah and its utilization well as a form of religious activity that must go hand in hand with the purification of the soul. The development of Islamic knowledge is not just to acquire knowledge and use it in accordance with needs (Golshani, 2004). The orientation in avoiding unfounded judgment is important because it is related to experiments conducted with involving unexpected risks. Based on Q.S. Al Isra' [17]: 36, that all the channels of human knowledge will be asked for accountability, then the development of science must be done carefully and based on solid foundations, not merely an unfounded judgment, not based on knowledge (Golshani, 2004). The Qur'an as a source of knowledge has illustrated how the nature of humanity starts from the origin of human creation, the potential given by God to humans, and the tasks and objectives of human creation itself (Kurniawati \& Bakhtiar, 2018).

An important aspect of I-SETS learning is that science learning not only provides information related to the concept of science, but also provides assistance to learners to clarify the values associated with Islamic values contained in the development of science, as well as aspects of the usefulness of science to the community, Environment, and its applicability to aspects of technology. Figure 2. shows the learning activities with the I-SETS learning design. The I-SETS learning design is based on four levels of activity related to I-SETS, which consists of I-SETS foundation, I-SETS Issues Awareness, I-SETS Issue Investigation, and Action Skill Development.

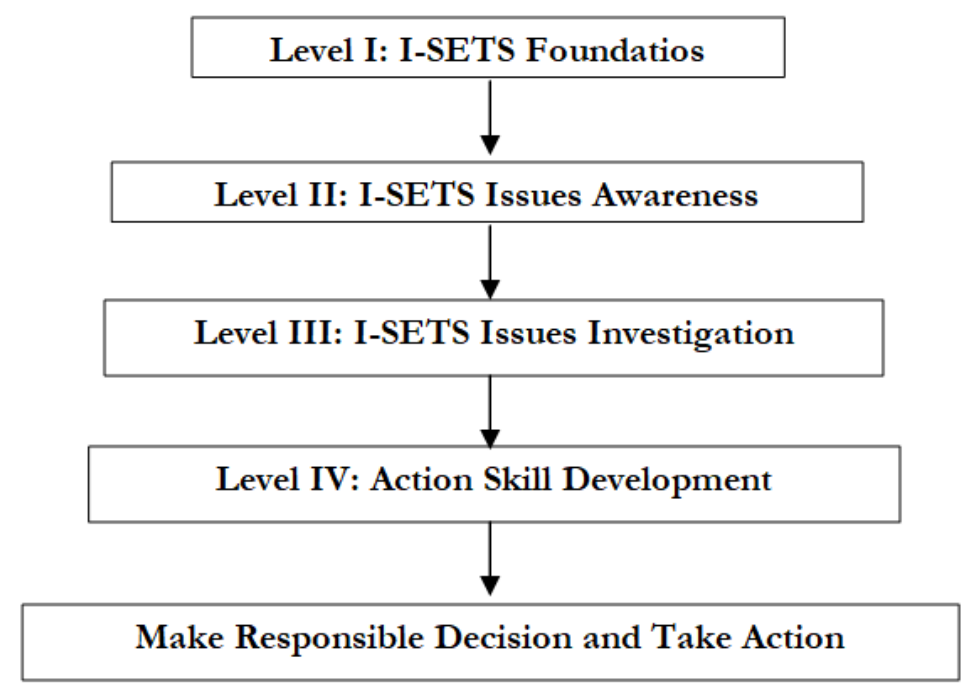

Figure 2. I-SETS learning design for pre-service science teachers

\section{LEVEL I: I-SETS Foundations}

At this level, learners (in this case is pre-service science teachers) are required to identify concepts related to issues in science and technology, as well as their impact on society and the environment. Golshani notes the four destructive effects of modern science for mankind: (1) excessive exploitation of natural resources, (2) environmental pollution, (3) sharp divide between rich and poor, (4) damage to the spiritual dimension (Golshani, 2004). The first and second destructive impacts can be explored further through science learning. More widely, these alternative global problems can be referred to Bybee's study of surveying scientists and engineers to show the rankings of global problems. Based on the study, obtained some global problems (R. Bybee, 1984), namely: (1) Population and growth, (2) War Technology, (3) World hunger and food resources, (4) Air quality and atmosphere, (5) Water resources, (6) Land use, (7) Energy shortages, (8) Hazardous substance, (9) Human health and disease, (10) Extinction of plants and animals, (11) Mineral resources, (12) Nuclear reactors. 
With the I-SETS point of view, global problems are identified by looking at the interconnectedness between the components of science, environment, technology, and society with relying on Islamic values sourced from the Qur'an, Sunnah, and ijtihad ulama'. The vision of I-SETS is demanding in providing the perspective of solving the problem of interdisciplinary science, both natural sciences and other social sciences. The I-SETS foundation can be designed to include a unifying theme related to energy changes, energy fields, energy interactions, models, systems or energy transfer, evolution, stability, change patterns, interaction systems, and scale and measurement. For example, presented a module or teaching material on " The Collision of Oil Tanker Ships at Sea", the concept of the I-SETS foundation may include system, energy change, scale and measurement, and interaction. If learners investigate oil spills, they can explore the effects of oil interactions on oceanic systems. The following illustrates the issue of the oil spill in Figure 3.

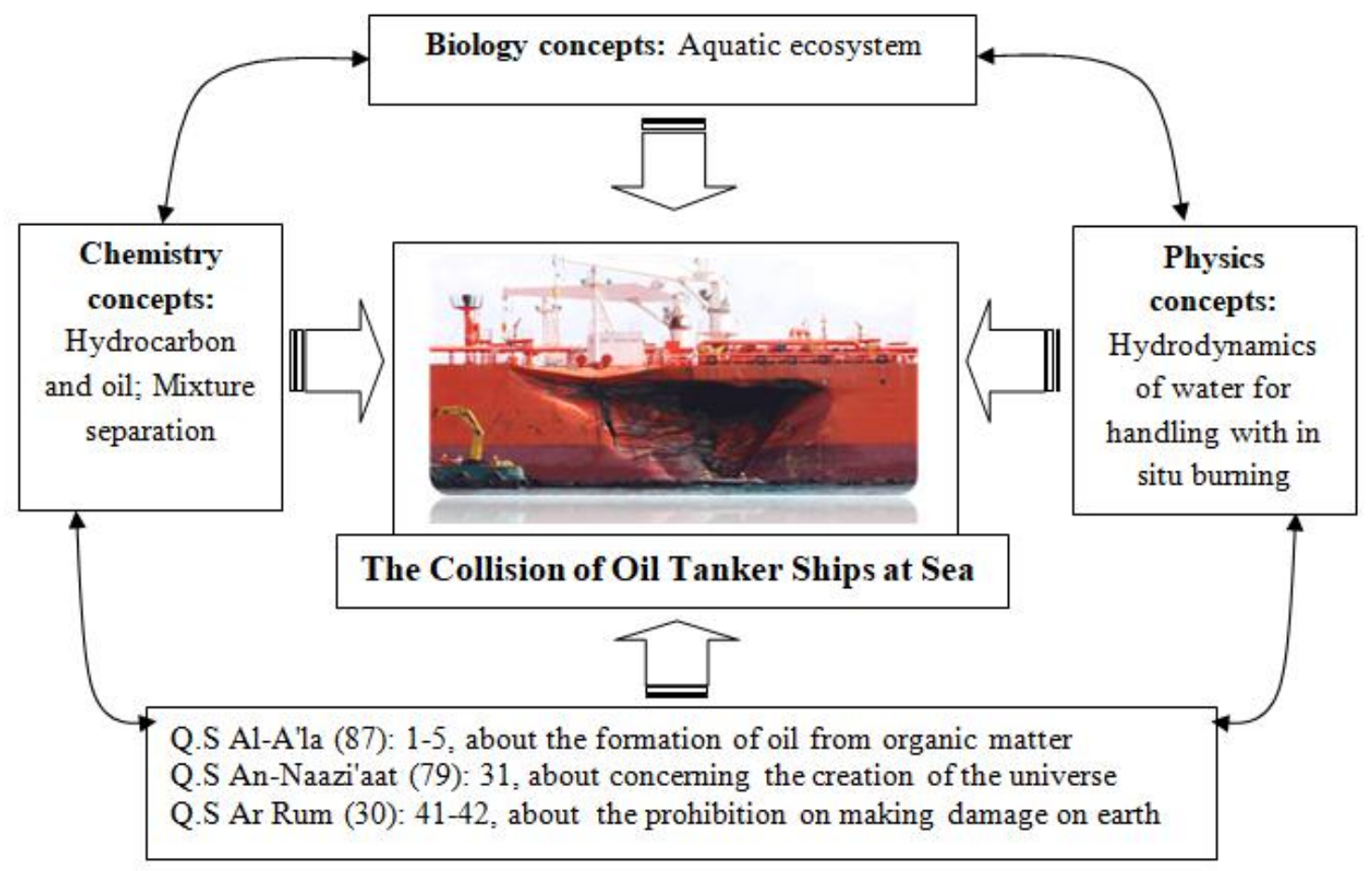

Figure 3. Illustration of oil tanker ship crash on incidents at the border of kepualauan riau (3/1/2017) realized through the vision of $i$-sets. The figure was modified from damanik, 2017.

At this level, the unifying concept and theme are chosen to lead learners to new ways of thinking. Facts and concepts are not taught linearly (Biology concepts, Chemistry concepts, and Physics concepts), but are taught in the context of an issue (Figure 3). In the case of "The Collision of Oil Tanker Ships at Sea", one article was selected related to the incident that occurred at the border of Kepulauan Riau province. Learners connect ideas to think holistically. In this case, concepts are deemed interdependent and interdisciplinary. For example, learners are required to analyze the potential and geographical location of the occurrence of oil-loaded crash incidents in Kepulauan Riau. Besides, it is also viewed regarding parties related to the incident. Finally, learners engage in exploring key ideas not only for their own interests but as constructs that are useful to help them solve relevant social and global problems. The foundation level should also show students how Islamic values are embedded in the science and technology that interact and show their interdependence.

The illustrations developed through examples made with the unifying theme of "The Collision of Oil Tanker Ships at Sea" are an extension of the Core Competencies(KI) and Basic Competencies (KD) in the curriculum structure of SMP/MTs Class VII, as described in Table 1. 
The lesson plan can be arranged with the vision of I-SETS as an effort to Islamize science at the level of pre-service science teachers who act as an understanding breaker of scientific dichotomy.

Table 1. Core Competencies (KI) and Basic Competencies (KD) in science subjects at the SMP/MTs level (Badan Penelitian dan Pengembangan, 2013) that can be developed through the unifying concept and theme of "Oil Spills" in the I-SETS design

CORE COMPETENCIES (KI)

1. Understanding and practicing the 1.1 Admiring the order and complexity of God's creation about teachings of religious beliefs.
BASIC COMPETENCIES (KD) the physical and chemical aspects, life in ecosystems, and the role of humans in the environment and realize it in the practice of religious teachings

2. Appreciating and exploring honest behavior, discipline, responsibility, care (tolerance, mutual cooperation), polite, confident, in interacting effectively with the social and natural environment within the reach of relationships and their existence
2.1 Demonstrating scientific behavior (have a curiosity; objective; honest; conscientious; careful; diligent; cautious; responsible; open; critical; creative; innovative and care for the environment) in daily activities as a form of implementing attitude in conducting experiments and discussion.

3. Understanding knowledge (factual, 3.5 Understanding the characteristics of substances, as well as conceptual, and procedural) based on curiosity about science, technology, art, culture related to visible phenomena and 3.7. Understanding the concepts of temperature, expansion, heat, events.

\begin{abstract}
physical and chemical changes in substances that can be used for daily life (for example mixed separation)

heat transfer, and their application in the mechanism of maintaining stable body temperature in humans and animals as well as in everyday life

3.8. Describing the interactions between living things and their environment

3.9. Describing pollution and its impact on living things
\end{abstract}

4. Trying, processing, and presenting in the 4.5. Separating mixtures based on physical and chemical properties concrete domains (using, unraveling, 4.12. Presenting the results of observations of the interaction of composing, modifying, and making) and living things with the surrounding environment abstract domains (writing, reading, 4.13. Presenting data and information about global warming and calculating, drawing, and composing) following what is learned in schools and other similar sources in point of view/ theory

Associated with KI 2 leading to the basic competence of scientific behavior, Golshani provides the principles of scientific attitude outlined by the Qur'an as part of its value in the realm of methodology. These principles include: (1) avoiding negative subjectivity called lust impulse (Q.S 6: 119), (2) diligent and meticulous in avoiding a hasty conclusion (Q.S. 21:37, 49: 6), (3) open to the truth and avoid egoism and arrogance (Q.S 71:17), (4) critical thinking, not simply following an opinion (Q.S 33:67, 2: 170), (5) avoiding unfounded conclusions (Q.S 3: 66, 22: 8), (6) avoids the prejudice (Q.S 45:24, 53:28), (6) maximizes the use of all tools for acquiring knowledge responsibly: senses, mind, and intuition - not just senses and mind, like the general view in Western science (Q.S 17:36, 62: 4) (Golshani, 1998).

\section{LEVEL II: I-SETS Issues Awareness}

At this level, a series of lessons are planned to help learners realize how the interaction between I-SETS components to generate controversy on an issue. The offered activities help 
learners to investigate (a) different perspectives on existing issues, (b) feelings and attitudes affecting the problem, and (c) alternative solutions to problems. Continuing with previous examples of "The Collision of Oil Tanker Ships at Sea " incident, learners may explore on:

(1) Specific negative impacts associated with the environment and fishing communities in the area of oil spill incidents,

(2) The extent to which stakeholders play a role in solving incidents related to solutions through technologies offered in the process of cleaning up oil spills in the marine area, the process of post-incident ecosystem recovery, as well as solutions in the form of economic compensation for affected communities.

(3) What efforts can be taken to prevent similar incidents in the future?

Aspects of learners' awareness related to their position as part of society that has literacy on aspects of science and technology. Indirectly, this leads to a meaningful moral orientation as useful knowledge and take into account aspects of natural balance. Awareness and clarification activities of those values can be applied through various strategies such as:

\section{1) Value Dilemma Sheets (VDS)}

The VDS contains a provocative (or illustrated) statement and a series of questions. The purpose of the given statement is to bring up I-SETS issues that have an important impact on the learner. Specific design questions through the process of clarifying values (choosing, prizing, acting). VDS is used individually to provide opportunities to reflect dilemmas, write responses, and may be used in small group discussions. Large group discussions have not been required to clarify judgments made by learners.

\section{2) I-SETS Action Dramas}

Another term that may be appropriate is roleplaying or socio dramas allowing learners to become leaders in exploiting I-SETS issues. This method is effective if learners are freed in thinking of their own approach. The most important thing is that educators can establish a condition in which learners can temporarily take on a new character, express the idea, and then reflect on it (with the whole class participating). Sources of ideas from these activities may include newspapers (especially papers that regularly feature debates), congressional decisions, new acts and laws, environmental incidents (accident), and issues related to science and technology displayed in textbooks.

\section{3) Action Voting}

Voting is a survey study in which learners are asked to vote on questions related to a particular topic. Voting is an action that citizens can take on related issues, and their voices confirm the choices they make about an issue. To use the method of voting in the class, put up a ballot. Each learner is required to complete the ballot independently, and then summarize the results on graph paper or the board.

\section{4) Case Studies}

Case Studies are learning strategies that are most likely to be applied to the I-SETS design through the analysis of problems or current issues.

\section{5) Online Discussions}

In this strategy, educators create an online environment for learners to discuss I-SETS issues. For example, the issue of the constraints to overcome oil spill incidents in the sea due to all ports in Indonesia does not yet have a Local Contingency Plan for Oil Pollution, management of hazard mitigation from oil spills

\section{LEVEL III: I-SETS Issues Investigation}

At this level, students are taught how to investigate problems through training in problem identification skills including identification of problems and statements, use of secondary sources, and collection of data through primary sources, data analysis, and conclusions. Students then apply 
the new skills needed to investigate the real problems that surround them. For example, the resolution of the case and the unifying theme of "Oil Spill in the Sea" will be used as a way of thinking to tackle other pollution cases that are closer in the area of students, such as river pollution due to the waste dumped carelessly by the community. At this stage an action project can be implemented consisting of six stages:

(1) Problem Identification. Learners put forward a spontaneous idea of a problem or situation to improve the local community.

(2) Fact-Finding. Learners make sure that the issues they are raising are present or exist. They can obtain information from (1) community resources, (2) national and international organizations, (3) opinions, (4) resource persons, and (5) independent and group studies.

(3) Problem Selection and Definition. Learners choose one or two existing problems, and if problems were solved, it can make a big change. Learners must decide whether they have the tools and resources available to solve the problem.

(4) Brainstorming Solutions: Learners pose various possible solutions to the problem.

(5) Evaluating Solutions: Learners determine the order of effectiveness of their solution and choose two to three top ideas. They include criteria to help them decide the best solution.

(6) Taking Action: This stage is the transition stage to level IV. Learners decide what strategy or action is most effective for solving the problems posed on the I-SETS design. Learners create a timeline for real action.

\section{LEVEL IV: Action Skill Development}

This stage requires students to provide a real action on the problems raised in the design of I-SETS. In the case of the "Oil Spill in the Sea" exemplified earlier, the case could be extended to the potential for pollution of the aquatic environment by various human activities. Understanding of students is explored on the role of humans as the caliph of God to act to provide solutions to these problems. These actions can be realized through a campaign agenda in the preservation of the aquatic environment through online or offline media. It is also a practice of QS Ar-Rum (30): 41-42 about the Prohibition of Making Damage on Earth. Also, their actions must be oriented towards sustainability and make an impact in the future.

Based on the I-SETS design that has been described, the Qur'an must be used as a reference or as a book of guidance. This is in line with Golshani's thought that the Qur'an is used as a reference to the principles and values in thinking about science. From the Qur'an, a basic view of reality as a whole is taken as a scientific basis with physical phenomena in the universe. This view does not make the Qur'an as a book of science even though it explains natural phenomena, even though it is following modern scientific theory (Golshani, 1998). It should also be emphasized that the main purpose of the Qur'an explains that the phenomenon is not to provide a scientific explanation, but rather to touch the conscience of humans in knowing the majesty of Allah SWT. Besides, the Hadith is also used to underlie learning related to the priority of seeking knowledge, without distinguishing the type. The I-SETS vision provides space for students to explore the multidisciplinary linkages of science related to applied science, mathematics, economics, sociology, and even culture. In the end, the Islamization of science that was designed with the vision of I-SETS for pre-service science teachers carried meaning as a science that was nuanced to Islam or following Islamic teachings, not just science applied by the Islamic community or science that was completely different from modern science. Science learning integrated with Islam can broaden scientific horizons while strengthening religious beliefs (Rahmawati \& Bakhtiar, 2019). 


\section{CONCLUSION}

I-SETS which is designed for pre-service science teachers leads to efforts to break the chain of science dichotomy that often occurs in the community. Pre-service science teachers are expected to be agents who transfer Islamic understanding through science subjects they teach in the future. I-SETS carries the message that knowledge originates from the same source, Allah, the Creator, which is manifested in the verses of qauliyah (al-Qur'an and Sunnah) and verses of kauniyah (the universe and its contents). Natural science ( $\mathrm{S}$, science) that is used in the form of technology ( $\mathrm{T}$, technology) in meeting the needs of society ( $\mathrm{S}$, society) requires thinking about various implications for the environment (E, environment). The development of I-SETS as a perspective can be harmonized with the perspective of Golshani in seeking the use of God's gifts to regulate society for eternal happiness which is also referred to as the "Divine goals". Four concepts are relevant to the moral orientation of the development of science and technology, namely: (1) useful knowledge, (2) balance, (3) purification of the soul and (4) avoiding unfounded judgments.

The I-SETS learning design is based on four levels of activity regarding I-SETS issues, which consist of I-SETS foundation, I-SETS Issues Awareness, I-SETS Issue Investigation, and Action Skill Development. The fourth level of activity is ultimately related to the decision-making and responsible actions towards the application of science in the form of technology, and its impact on society and the environment.

I-SETS design is a thought that requires execution in the form of a concrete design including lesson plans, teaching materials, and evaluation instruments. Also, further testing of design implementation is needed to see the suitability of pre-service science teachers in various lectures related to pedagogical content knowledge of science educators in the 21st-century era, such as Physics, Biology, Chemistry, and Science Practicum courses and Salingtemas (Science) courses, Environment, Technology, and Society) held in several Teacher Education Institute.

\section{REFERENCES}

Amril, A. (2018). Nilainisasi Pembelajaran Sains (Upaya Pembelajaran Integrasi-Interkoneksi Agama Dan Sains). Journal of Natural Science and Integration, 1(2), 133-144.

Badan Penelitian dan Pengembangan, K. P. dan K. (2013). Kompetensi Dasar Sekolah Menengah Pertama (SMP)/ Madrasah Tsanawiyah (MTs). Kementrian Pendidikan dan Kebudayaan.

Binadja, A. (2005). Pedoman Pengembangan Silabus Pembelajaran Berdasar Kurikulum 2004 Bervisi dan Berpendekatan SETS (Science, Environment, Technology, Society) atau (Sains, Lingkungan, Teknologi, dan Masyarakat). Laboratorium SETS Unnes Semarang.

Bybee, R. (1984). Global Problems and Science Education Policy. In R. W. Bybee, J. Carlson, \& A. J. McCormack (Eds.), Redesigning Science and Technology Education. National Science Teachers Association.

Damanik, C. (2017). Tabrakan Kapal Tanker Sebabkan 300 Ton Minyak Tumpah, Kepri Waspada Kompas.com.

https://regional.kompas.com/read/2017/01/06/18550561/tabrakan.kapal.tanker.sebabkan .300.ton.minyak.tumpah.kepri.waspada

Dick, \& Carey. (1994). The Systematic Design of Instruction. Harper Collins Publishers.

Golshani, M. (1998). The Holy Qur'an and The Science of Nature. Global Publications.

Golshani, M. (2004). Issues in Islam and Science. Institute for Humanities and Cultural Studies.

Imaduddin, M. (2019). Infusing Islamic Values and Sustainable Development Into Chemistry for Pre-Service Islamic Elementary School Teachers. Jurnal Pendidikan Sains (Jps), 7(1), 47. https://doi.org/10.26714/jps.7.1.2019.47-54

Imaduddin, M., \& Khafidin, Z. (2018). Ayo Belajar IPA dari Ulama: Pembelajaran Berbasis SosiScientific Issues di Abad ke-21. Thabiea: Journal of Natural Science Teaching, 01(02), 102-120. 
Kosim, M. (2013). Menyoal Islamisasi Sains Di Madrasah (Studi Atas Kandungan Agama Islam dalam Buku Ajar Sains di Madrasah Aliyah). In A. C. Secretariat (Ed.), 13rd Annual International Conference on Islamic Studies (pp. 109-124). Subdit Pengembangan Akademik, Direktorat Pendidikan Tinggi Islam Kementrian Agama Republik Indonesia.

Kurniawati, E., \& Bakhtiar, N. (2018). Manusia Menurut Konsep Al-Qur`an dan Sains. Journal of Natural Science and Integration, 1(1), 78-94. https://doi.org/10.24014/jnsi.v1i1.5198

Mahfud, M. (2018). Mengenal Ontologi, Epistemologi, Aksiologi Dalam Pendidikan Islam. CENDEKIA: Jurnal Studi Keislaman, 4(1). https://doi.org/10.37348/cendekia.v4i1.58

Minhaji, A. (2004). Transformasi IAIN Menuju UIN: Sebuah Pengantar. In M. A. Abdullah (Ed.), Integrasi Sains-Islam: Mempertemukan Epistemology Islam dan Sains (1st ed.). Pilar Religia.

Minhaji, A. (2007). Masa Depan Perguruan Tinggi Islam di Indonesia; Perspektif Sejarah-Sosial. Tadris Jurnal Pendidikan Islam Jurusan Tarbiyah STAIN Pamekasan, 2(2), 154.

Muslih, M. (2010). Pengaruh Budaya dan Agama Terhadap Sains Sebuah Survey Kritis. Tsaqafah Jurnal Peradaban Islam, 6(2), 234.

National Science Teachers Association. (2003). Standards for science teacher preparation.

Rahmawati, R. D., \& Bakhtiar, N. (2019). Pembelajaran IPA Berbasis Integrasi Islam-Sains pada Pokok Bahasan Penciptaan Alam Semesta dan Tata Surya. Journal of Natural Science and Integration, 1(2), 195. https://doi.org/10.24014/jnsi.v1i2.6599

Rifenta, F. (2019). Konsep pemikiran Mehdi Golshani terhadap sains Islam dan modern. Kalimab: Jurnal Studi Agama-Agama Dan Pemikiran Islam, 17(2), 165-183.

Salafudin, S. (2013). Islamisasi Ilmu Pengetahuan. Edukasia Islamika, 11(2), 194-216.

Wilujeng, I. (2010). Kompetensi IPA Terintegrasi Mahasiswa Pendidikan IPA dengan Pendekatan Sains-Teknologi-Masyarakat (S-T-M) Mahasiswa S1 Pendidikan IPA. Jurnal Ilmiab Pendidikan.

Wisudawati, A. W., \& Sulistyowati, E. (2014). Metodologi Pembelajaran IPA. Bumi Aksara.

Zainiyati, H. S. (2016). Islamisasi ilmu pengetahuan (sains) sebagai upaya mengintegrasikan sains dan ilmu agama: Tawaran epistomologi bagi Universitas Islam Negeri. Prosiding Halaqoh Nasional \& Seminar Internasional Pendidikan Islam Fakultas Tarbiyah Dan Keguruan UIN Sunan Ampel Surabaya, 395-411. 